\title{
sciendo
}

\section{SUSTAINABLE URBAN LANDSCAPE MANAGEMENT: AN INSIGHT INTO URBAN GREEN SPACE MANAGEMENT PRACTICES IN THREE DIFFERENT COUNTRIES}

\author{
FAIZA DARKHANI*, OSMAN MOHD TAHIR, ROZIYA IBRAHIM
}

\begin{abstract}
Department of landscape architecture, Faculty of design and architecture, University Putra Malaysia, 43300 Serdang Malaysia

Corresponding author e-mail: faiza.darkhani@gmail.com
\end{abstract}

Received: $13^{\text {th }}$ December 2018, Accepted: $2^{\text {nd }}$ January 2019

\begin{abstract}
To achieve high-quality urban landscape management, it is important to have a proper management system. Some developing countries like Afghanistan are facing a decline of green spaces due to lack of proper management. This is a qualitative study with content analysis which provides a brief review of the management system in three selected countries, namely England, Malaysia and Singapore, by examining their urban landscape management systems. It also highlights the importance of establishing more appropriate programs to achieve the goal of sustainability. The findings show that good and proper planning, as well as programs and activities in the local government system, can enhance and increase urban green space in urban landscape. The contribution of this paper is to increase the local authority's knowledge of managing the urban landscape and decreasing the deterioration and decline of urban green spaces in urban landscape.
\end{abstract}

Keywords: Sustainable Urban Landscape Management, Urban Green Space, Sustainability, Urban Landscape, Sustainable Development

\section{INTRODUCTION}

Urban landscape structure has come about as the result of a rapid increase in population, the evolution of city areas and the concept of dense areas (Brown, 2018). Recently, urban green space has decreased in some urban areas (Rakhshandehroo et al., 2016). For the present and future development of urban landscapes, it is better to focus more on sustainable urban development, green solutions, and the management and governance of green areas in the landscape (Jansson \& Lindgren, 2012). Effective management depends on good governance (Shields et al., 2016).

Unsustainable urban landscape management causes air, water and soil degradation (Rakhshandehroo et al., 2015). Concerning good planning, more sustainable approaches (Pearson \& Moon, 2014) are needed in the management of urban landscapes (Tahir \& Roe, 2006). Sustainable urban landscape management has been overlooked (Gillette \& Hurley, 2018) from the policy maker's perspective (Shields et al., 2016).

Landscape management in complex, spanning jurisdictions is often limited by the lack of shared management priorities and a common spatial information system in Kabul Afghanistan (MAIL, 2016). For comprehensive sustainability of urban landscape 
management, including open green spaces, landscape management is critically needed (Mahayudin et al., 2015). Landscape management is connected to the managing organization and all others with which it works (Jansson \& Lindgren, 2012).

Many other studies such as Ojeda-Revah et al., (2017) articulated that in some countries landscape planning and management are not statutory. They are mostly carried out through a wide range of powers generated by national, regional, and local laws. In addition, they are often the responsibility of the local government. As a result of the lack of a comprehensive legal framework and proper enforcement, landscape planning and management in these countries do not meet the expectations or needs of the potential users.

Thus, this paper provides a brief review of the management systems in three selected countries, namely England, Malaysia, and Singapore, by examining their landscape management systems in the context of providing and enhancing urban green space. This paper provides a general definition of urban landscape management and discusses the contribution of knowledge to landscape best management practices through a proper management system.

\section{LITERATURE REVIEW}

\section{Defining urban landscape in terms of landscape management}

There are many different definitions of urban landscape depending on the context in which it is being used. Some definitions include a land, landscape elements or a piece of land consisting of greenery and water which is used or perceived by the people (McGarigal, 2014). According to Osman, (2005) urban landscape has been defined as the overall urban space which forms the character of a town or city. This space includes parks, green corridors, open green spaces, and other spaces between and within the area, greatly benefiting urban dwellers in their everyday lives. Urban landscape is defined by the Latin American Landscape Initiative as the outcome of natural and social activities which have been shaped by the people. Urban landscapes have a user-defined pattern that is imagined to influence its purpose. This relationship between space and pattern is called landscape concept (Nölting \& Mann, 2018). Landscapes can also be seen as a mixed land space shaped of a cluster of interrelating ecosystems that are repeated in similar form throughout (Strien et al., 2016). The function of the urban landscape is to provide for biological biodiversity, greening the environment, producing (Shaker, 2018) clean water, etc. (McGarigal, 2014). The characteristics of an urban landscape are as follows:

1. It has natural and cultural values which emphasize the relationship between these two.

2. It is more than what we think we see in the world; it has social, cultural and artistic elements, including physical and metaphysical perspectives.

3. Urban landscape management works to save the landscape for now and for future generations.Additionally, the current landscape is the result of all past generations' changes to the environment. So, it is where the past and present people can have their needs met.

4. Urban landscape provides uniqueness to the environment and adds diversity to the setting of peoples' lives.

In summary, urban landscapes can be defined in many ways. In this paper, the focus will be on the management of urban green spaces such as parks, green corridors, and green spaces within urban areas. From the above definitions of urban landscape it can be said that urban landscape is the green areas found all around in an urban field. 


\section{The concept of sustainable development}

Sustainable development is not just preserving a certain type of land; it also includes maintaining the natural, cultural and environmental (Uyl \& Driessen, 2015) dimensions of urban green space (Rakhshandehroo et al., 2015). The concept of sustainable development involves maintaining rural and urban land for the present and the future(Jansson et al., 2018). It should also be improved for the future (Mann et al., 2018). Sustainability isconnected to urban expansion and globalization in the world, and it is dependent on the planning and management of countries around the world (Cumming et al., 2017). From another perspective, sustainability is about the sustainable development of economic, environmental, and societal components (Baycan-Levent \& Nijkamp, 2009; DCLG, 2012; Yoong et al., 2017).

\section{Sustainable urban landscape}

Sustainable urban landscape is more than environmental, human and cultural sustainability. It also includes biodiversity, people, their needs, and attitude toward their habitat (Yoong et al., 2017). Sustainable development is a type of development where by people can achieve their needs without limiting the next generations (Geh \& Sharp, 2008; Kumar, 2014). Sustainable landscape has become a critical problem in developing countries because there are not proper management programs (Kalantari et al., 2018).

There is a need for strategic urban landscape planning to save the environment and increase human comfort (Pearson \& Moon, 2014). Sustainable urban landscape is based upon three dimensions of sustainable development: social, environmental, and economic (Stauffacher \& Krütli, 2016). The goal is to create a healthy, livable urban landscape which is economically viable (Jansson et al., 2018). Sustainable urban landscapes can be described in different ways: A sustainable urban landscape increases the environment quality where possible (Uyl \& Driessen, 2015). According to Solecka et al., (2018), urban landscape is still not a subject of international debate because it faces a lack of attention from environmental policymakers and environmental lawyers. There continues to be little attention to landscape conservation, the release of pollution, etc.

\section{Sustainable Landscape Management}

A holistic meaning of management, according to the Oxford English Dictionary, is the procedure of controlling or guiding people or things. In relation to urban landscape, it can involve the management of both people and space, mainly by those involved with management organizations (Fernandes et al., 2018). Urban landscape management is defined as the management of open spaces and greenspaces, like residential green spaces, parks, playgrounds, etc. (Anguluri \& Narayanan, 2017). For the sustainable development and management of urban landscapes, many different actors and organizations should be included (Albert et al., 2016). Urban landscape management and sustainable development require proper governance and supervision. Hence,the continuous development of social, economic and environmental factors will be an essential requirement to achieve the goal of sustainability (Jansson \& Lindgren, 2012). Urban landscape management has been introduced here as a general concept that mainly emphasizes green area management and development processes. It also includes other fields like planning and organization, open space management, as well as general management skills. 
Darkhani F., Mohd Tahir O., Ibrahim R.: Sustainable Urban Landscape Management: An Insight into Urban Green Space Management Practices in Three Different Countries

\section{Characteristics of the areas of study: England, Malaysia and Singapore}

Three countries were chosen for this study: Singapore, England, and Malaysia. Malaysia was recognized as a national tropical garden in 2005 (Firdaus et. al., 2018). Malaysia has the vision to become a developed country by 2020 and aims to create a national park system and be designated the most beautiful garden nation by the year 2020 (Akmar et al., 2011).

Prakash \& Tan (2014) claim that Singapore can be a role model for other cities in the case of green management and sustainable development- it even has the title of Garden City.Singapore has one of the highest per person incomes in Asia. It has a 40-50 year development plan based on five main targets: a worthy living environment, complete society, economic development, a sustainable Singapore, and comfortable home for the public (Henderson, 2013).

In the case of England, London is known as the greenest city in the world (Londonassembly, 2018). England has a standard requirement of 6 acres to be set aside as a recreation area for every 1000 people (Wilson \& Hughes, 2011). England's priority is on increasing the quality of urban green space over quantity (England, 2008).

\section{METHODOLOGY}

This review was conducted using a qualitative research strategy with content analysis in searching for the best management practices found in these countries. Case studies of sustainable urban landscape management in the countries of England, Singapore and Malaysia were selected. For each, a review as doneon the governance of sustainable landscape management in the context of urban green space. The information was gathered through articles, reports, screen study, document analysis, and the study of government websites. Lastly, the researcher used a descriptive analysis strategy to simplify the research process. The analysis is comprised of content and descriptive analysis.Fromeach country's best management practices, a preliminary framework has been made for the benefit of countries who lack best management practices. The aim is to identify the best management practices seen in selected countries since these countries can serve as role models for the green management of other cities.

\section{RESULTS AND DISCUSSION}

\section{Malaysia}

To achieve these visions, the authorities have focused more on the landscape and the greenery of the country. As a first step, a national landscape department has been established (Nor Akmar, 2012). This department focuses on leading and being the centre of excellence for landscape development in achieving a quality and sustainable living environment. Under this department, many different programs have been started. An example of research towards sustainable urban landscape management in Malaysia can be found in the project called "Green space planning and management in Malaysia" as reported by Akmar (2011). Challenges related to maintaining multifunctional green spaces in a time of rapid economic development and urbanization call for better implementation of policy and legislation, and of balancing national visions with local needs. Relevant programs implemented include a national planting campaign, a national garden, landscape extension and advisory, landscape research, national landscape nurseries, an annual celebration of national landscape day, and a landscape architecture program in the local institute of higher education (Nor Akmar, 2012). 
These programs focus on different dimensions of landscape management and maintenance. A nation-wide tree-planting campaign program has been put in place with the goal of being a garden nation. One million trees are being planted per year and public parks are being developed. The landscape architecture program in the local institute of higher education focuses on supporting government efforts in the landscape industry. A landscape architecture program has been introduced by several local institutes of higher education and training programs have been offered by local institutes (Tahir \& Roe, 2006; TKPK, 2018). From the policy perspective, some acts and policies such as a tree preservation order, landscape policy, and town and country planning have been establishedto follow the vision of greenery and sustainable landscape (KPKT, 2018).

Fig. 1: Landscape management practices in Malaysia

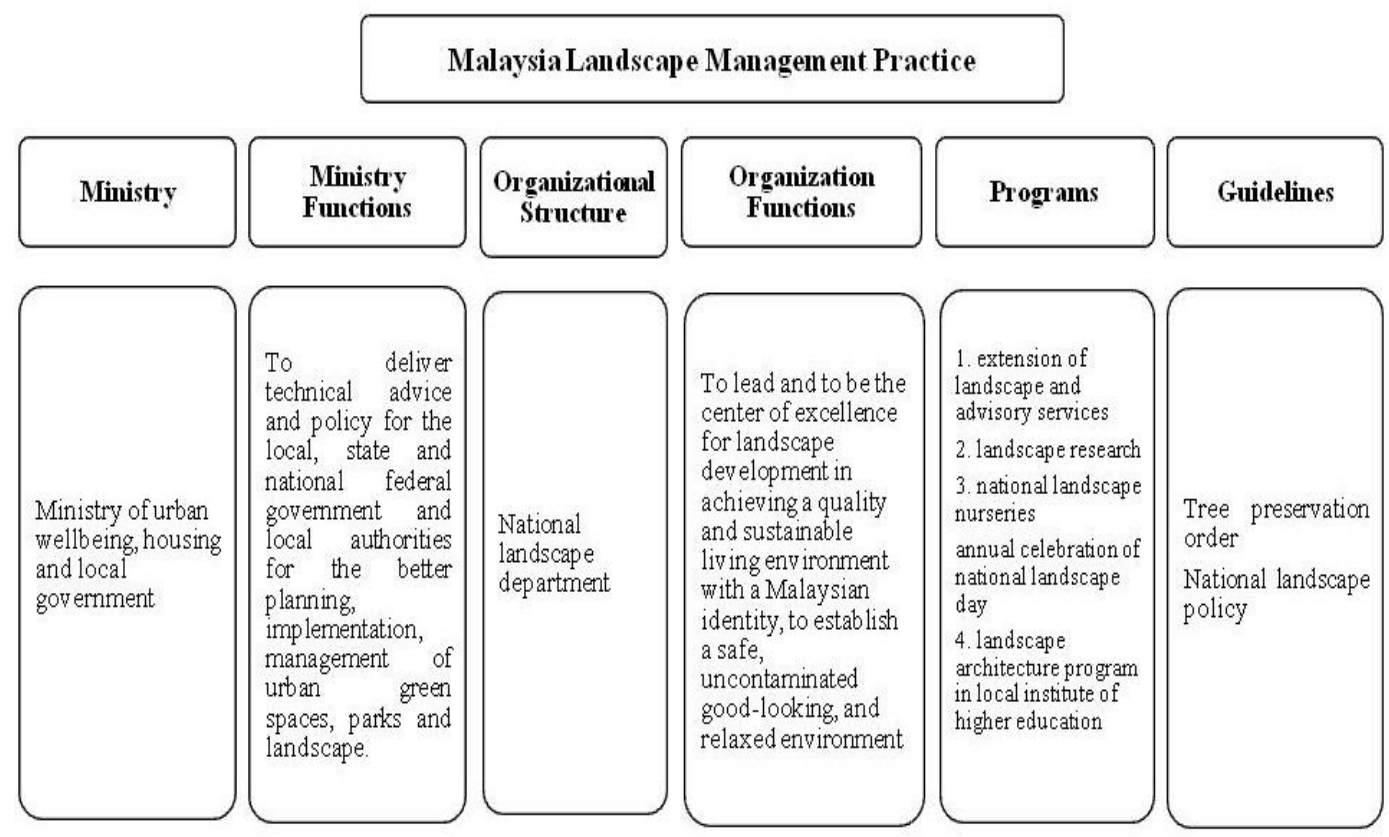

The municipality landscape recreation department has been focusing on greenery and landscape sustainability, with a particular focus on providing amenities for the public and working on the beautification of the city to achieve the goal of becoming a world-class sustainable tropical city by 2020 (Municipality) as shown in Figure 1. For Kuala Lumpur, a city of parks and facilities for all people, beautification programs and the establishment and maintenance of park areas are ongoing year to year (KPKT, 2018; TKPK, 2018).

\section{Singapore}

After about five decades of rapid urbanization, industrialization, and declining forests, Singapore gave more attention to urban greening as a main development objective (Tan et al., 2013). They had the idea to become a garden city in the world garden (Prakash \& Tan, 2014). Firstly, the country started a green program to create a green and clean city before issuing any other programs (Tan et al., 2013). In these areas, Singapore can be a role model for cities in 
Darkhani F., Mohd Tahir O., Ibrahim R.: Sustainable Urban Landscape Management: An Insight into Urban Green Space Management Practices in Three Different Countries

sustainable development. With its green landscape, it deserves the title of Garden City (Haaland et al., 2015; Gulsrud \& Ooi, 2015).

Singapore's vision for parks and green areas has changed over the years (Henderson, 2013). The country started off primarily by creating housing and employment for the people and by creating small parks by hand. After that, the program changed to the beautification of the environment and started planting different varieties of trees and shrubs for people's recreation. Eventually, the vision evolved to become a garden in a city for the people's recreation and the country's beautification. A national park has been established to take over all the responsibilities of landscape management and produce programs and guidelines to keep the city clean and green, as shown in Figure 2 (Mukherjee \& Takara, 2018). The National Park Board is the responsible public organization to facilitate these activities and programs.

Fig. 2: Landscape management practices in Singapore

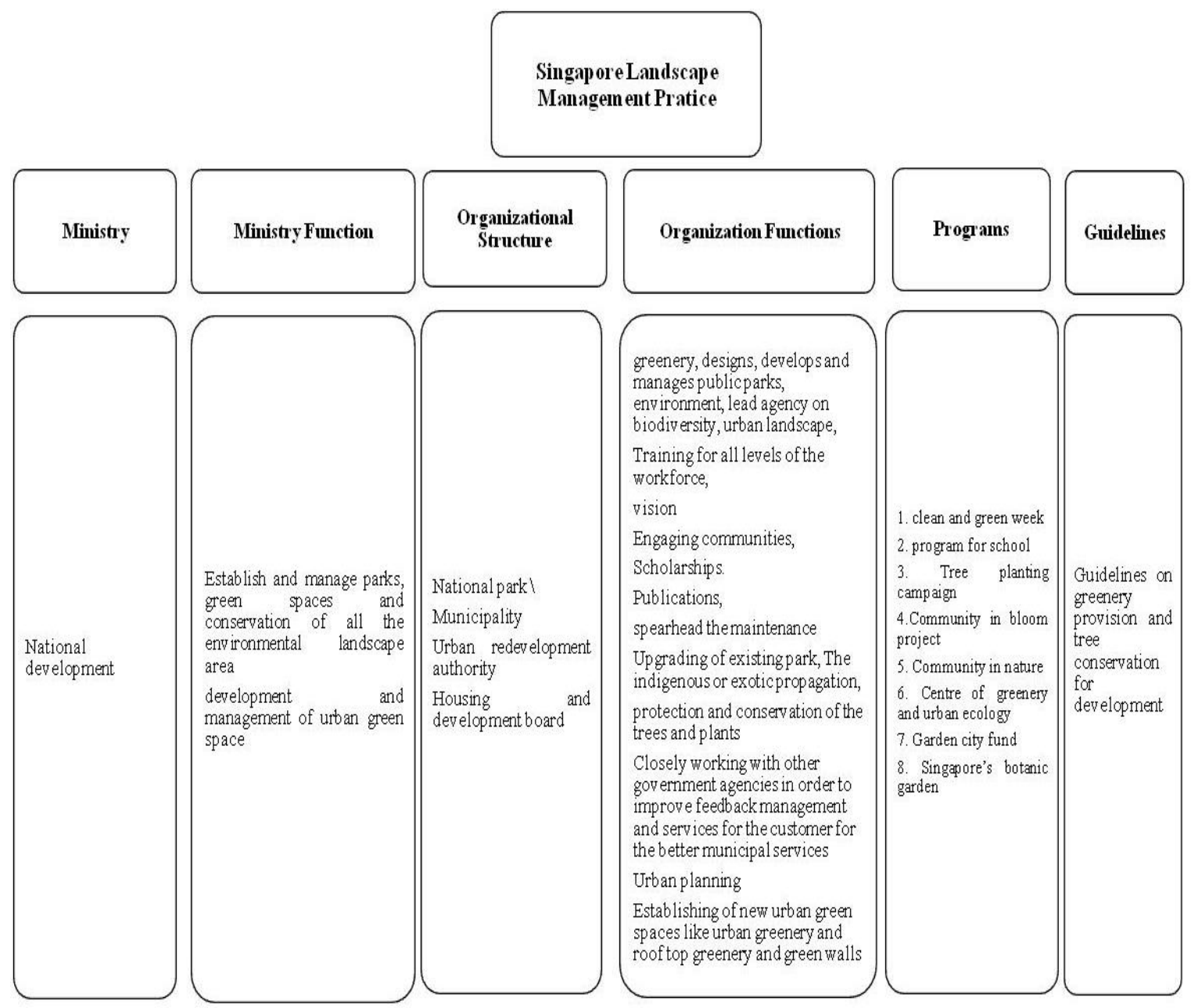




\section{England}

The Commission for Architecture and the Built Environment (CABE) is a strategic advisory organization for development and management that was established in 2003. The main objective of CABE space is working for the better design and management of parks and public green spaces in cities, establishing leadership, giving clear responsibilities to management units, consultant selection, distribution of green spaces, community engagement and stakeholder consultation, preparing green space strategies for better management, planning and design of urban green spaces, and establishing quality indicators (CABE, 2010). All the experts are accountable for developing and updating the urban open green space strategy. Each of the advisors offers support and guidance around the country. Thus, cooperative thinking and partnerships are essential for landscape management (C.A.B.E., 2004). Councils are responsible for the vision and details for providing, enhancing, and maintaining green spaces and parks. National planning came up with specific expectations from the local experts to form a strategic method for landscape management (C.A.B.E., 2004).

England evaluates the quality of their landscape through distinctiveness and connectivity. This can offer guiding information for developing landscape policies. There is a European Landscape Convection, established in 2000, whose members include most European countries including the United Kingdom. It has laws above the national level for the conservation, planning, and management of landscapes (De Montis, 2014; England, 2008, 2010). CABE has come up with a funding model to increase urban green space and claims that this funding can be used around the world (Space, 2006).

Fig. 3: Landscape management practices in England

\begin{tabular}{|c|c|c|c|c|c|}
\hline & & England Lant & e Managem ent Practice & & \\
\hline Department & Activities & $\begin{array}{l}\text { Organizational } \\
\text { Structure }\end{array}$ & Organizational Functions & Programs & Guidelines \\
\hline $\begin{array}{l}\text { Department of } \\
\text { Culture, Media } \\
\text { and Sport }\end{array}$ & $\begin{array}{l}\text { Keep and protect the } \\
\text { urban landscape and } \\
\text { cultural, and heritage } \\
\text { areas, help business } \\
\text { and public } \\
\text { communities to grow } \\
\text { and make Britain an } \\
\text { amazing green place } \\
\text { to visit and attract the } \\
\text { visitors attention. }\end{array}$ & $\begin{array}{l}\text { Trust fund } \\
\text { Natural England } \\
\text { Commission for } \\
\text { architecture and the } \\
\text { built environment } \\
\text { (CABE) }\end{array}$ & $\begin{array}{l}\text { Community engagement by grant } \\
\text { awarding } \\
\text { Regenerate historic parks } \\
\text { Contributing to sustainable dev elopment } \\
\text { England's natural env ironment, } \\
\text { promoting nature conservation and } \\
\text { biodiv ersity } \\
\text { conserv ing landscape } \\
\text { promoting access to the countryside and } \\
\text { open green spaces } \\
\text { Community engagement } \\
\text { Design and management of green areas } \\
\text { and parks in towns } \\
\text { planning and designing for parks and } \\
\text { urban green areas } \\
\text { local and people knowledge } \\
\text { improvement } \\
\text { local authorities and people skill } \\
\text { improvement } \\
\text { training for managers and people } \\
\text { council to improveurban green space } \\
\text { strategy } \\
\text { practical adv ice for the exp erts, local } \\
\text { authority and } \\
\text { Adv isor forthe well-designed building, } \\
\text { open spaces, green spaces and parks }\end{array}$ & $\begin{array}{l} \\
\text { 1. extension of } \\
\text { landscape and } \\
\text { advisory services } \\
\text { 2. landscape } \\
\text { research } \\
\text { 3. national } \\
\text { landscape nurseries } \\
\text { annual celebration } \\
\text { of national } \\
\text { landscape day } \\
\text { 4. landscape } \\
\text { architecture } \\
\text { program in local } \\
\text { institute of higher } \\
\text { education }\end{array}$ & $\begin{array}{l}\text { Tree } \\
\text { preservation } \\
\text { order } \\
\text { National } \\
\text { landscape policy }\end{array}$ \\
\hline
\end{tabular}


Darkhani F., Mohd Tahir O., Ibrahim R.: Sustainable Urban Landscape Management: An Insight into Urban Green Space Management Practices in Three Different Countries

London is already one of the greenest cities in the world ("Greener City Fund," 2018). From the above, it is obvious that they have maintained their plans and programs. Some of their policies, activities, experiences, and programs as shown in Figure 3 should be used in developing countries to sustain the landscape and keep it durable. This set of indicators provides numerous advantages; it gives managers the ability to identify strengths and weaknesses within their management and facilitates comparisons between similar areas within and among countries (Shields et al., 2016).

\section{CONCLUSION}

This review shows that the appropriate urban planning, programs, activities, and guidelines can lead to proper management. Ultimately, suitable management ensures the sustainability of the landscape of a country. This paper is the result of an analytical study of lessons learned from three countries. The research shows that urban landscape sustainability can be achieved with proper planning, implementation, organization, activities, availability, and usage of guidelines.

Each country has its own system for landscape management, which can be implemented by the community with close supervision of the local government. England has advisory organizations like $\mathrm{CABE}$ that prepare guidelines and strategic planning for the government to bring sustainability to urban green space in a landscape. Some of the countries applied effective measures and achieved landscape sustainability, for instance, Malaysia has established a landscape department, landscape day, trained people and had the vision to become a tropical garden city. The government of Singapore envisioned Singapore as a Garden City. To achieve this vision, the local government established national parks, prepared and approved landscape safe-keeping policies, and implemented several other measures to enhance urban green space in the city. They also hired trained technical and professional staff. These all form part of the best initiatives to ensure successful landscape sustainability in a country.

From the above studies, a preliminary framework is suggested for the urban areas of developing countries - especially for Kabul, Afghanistan - to employ in their urban landscape management system.

This paper offers best practices and lessons learned for developing countries, especially for those suffering from the declination and degradation of their open green spaces and landscape. It also includes best-proven principles that can be used as effective management tools to ensure and maintain urban landscape sustainability, extend landscapes and avoid degradation. Thus the authors propose the implementation of the management principles described in the "Preliminary framework for sustainable landscape management" to achieve landscape sustainability.

For those developing countries that suffer from a lack of proper management, the author recommends a ministry be designated to have the responsibility of managing the urban landscape. Under this ministry, some specific functions, such as the establishment, maintenance, and development of urban green spaces need to be taken in to account. Delivering technical advice and policy to the local and national authorities also should be under the functions of this ministry.

Having one specific organization for landscape in the ministerial structure is of great importance. Under this organization, many functions can be undertaken, such as developing vision, establishing greenery and public parks, encouraging community engagement, providing trainings, working for the protection and conservation of trees and plants, etc. 
Some specific programs and guidelines must be implemented, as shown in Figure 4, in order to have a proper landscape management and to cause people to take on the appropriate responsibilities.

Fig. 4: A preliminary framework for sustainable landscape management

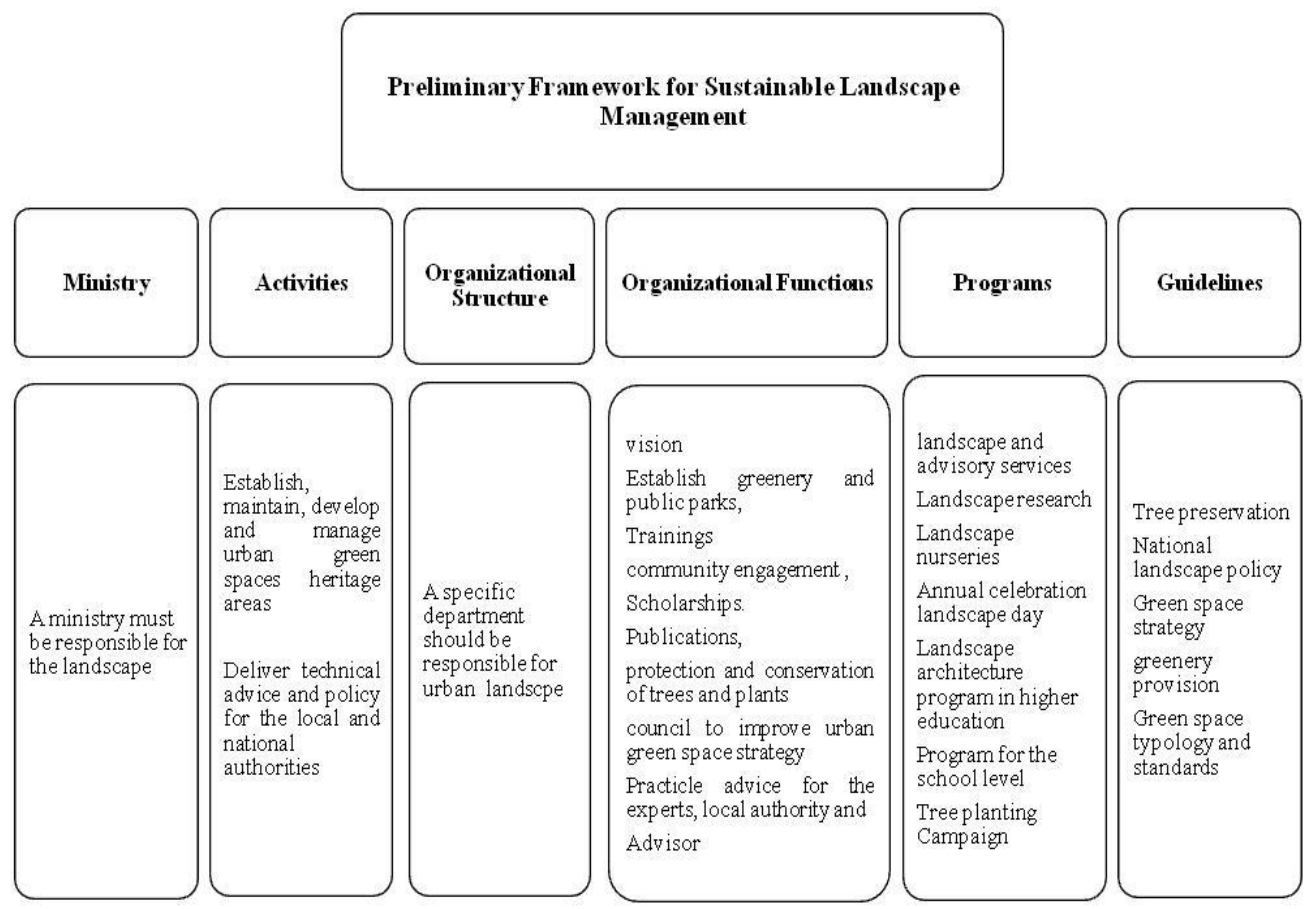

\section{REFERENCES}

Akmar, N., Konijnendijk, C., Maruthaveeran, S., \& Nilsson, K. (2011). Green space planning and management in Klang Greenspace Planning and Management in Klang Valley , Peninsular Malaysia. Arboriculture \& Urban Forestry, 99-107.

Albert, C., Galler, C., Hermes, J., Neuendorf, F., Haaren, C. Von, \& Lovett, A. (2016). Applying ecosystem services indicators in landscape planning and management: The ES-in-Planning framework. Ecological Indicators, 61, 100-113. https://doi.org/ 10.1016/j.ecolind.2015.03.029

Anguluri, R., \& Narayanan, P. (2017). Role of green space in urban planning: Outlook towards smart cities. Urban Forestry and Urban Greening, 25(April), 58-65. https://doi.org/10.1016/j.ufug.2017.04.007

Baycan-Levent, T., \& Nijkamp, P. (2009). Planning and Management of Urban Green Spaces in Europe: Comparative Analysis. Journal of Urban Planning and Development-Asce, 135(1), 1-12. https://doi.org/10.1061/(asce)0733-9488(2009)135:1(1)

Brown, H. C. P. (2018). An Assessment of Institutional Capacity for Integrated Landscape 
Darkhani F., Mohd Tahir O., Ibrahim R.: Sustainable Urban Landscape Management: An Insight into Urban Green Space Management Practices in Three Different Countries

Management in Eastern Cameroon. Environmental Management, 62(1), 118-127. https://doi.org/10.1007/s00267-018-1048-z

C.A.B.E., S. (2004). Green space strategies. A Good Practice Guide. Retrieved August 25, 2004, from http://webarchive.nationalarchives.gov.uk/20110118095356/http:/www. cabe.org.uk/files/green-space-strategies.pdf

Cumming, T. L., Shackleton, R. T., Förster, J., Dini, J., Khan, A., Gumula, M., \& Kubiszewski, I. (2017). Achieving the national development agenda and the Sustainable Development Goals ( SDGs ) through investment in ecological infrastructure : A case study of South Africa. Ecosystem Services, 27(May), 253-260. https://doi.org/10.1016/ j.ecoser.2017.05.005

DCLG. (2012). National Planning Policy Framework. Department for Communities and Local Government.

De Montis, A. (2014). Impacts of the European Landscape Convention on national planning systems: A comparative investigation of six case studies. Landscape and Urban Planning, 124, 53-65. https://doi.org/10.1016/j.landurbplan.2014.01.005

England, N. (2008). Understanding the Relevance and Application of the Access to Natural Green Space Standard. Natural England, London. Retrieved Juny 8, 2008, from http://publications.naturalengland.org.uk/publication/5081534874779648? category $=47004$

England, N. (2010). Nature Nearby: Accessible Natural Greenspace Guidance. Natural England: Peterborough.

Fernandes, J. P., Guiomar, N., \& Gil, A. (2018). Identifying key factors , actors and relevant scales in landscape and conservation planning, management and decision making: Promoting e ff ective citizen involvement. Journal for Nature Conservation, 47(November), 12-27. https://doi.org/10.1016/j.jnc.2018.11.001

Firdaus, R., Wibowo, P. M., \& Rochmayanto, Y. (2018). Developing Strategies for Landscape Sustainability: An Indonesian National Strategic Plan of Action in the Heart of Borneo. In Landscape Ecology for Sustainable Society (pp. 67-84). Springer, Cham. https://doi.org/https://doi.org/10.1007/978-3-319-74328-8_5

Geh, M., \& Sharp, I. (2008). Singapore's natural environment, past, present and future: A construct of national identity and land use imperatives. Spatial Planning for a Sustainable Singapore, 2, 183-204. https://doi.org/10.1007/978-1-4020-6542-2_11

Gillette, M. B., \& Hurley, A. (2018). Voice, and the community landscape: The Missouri Place Stories pilot project. Landscape and Urban Planning, 173(January), 1-8. Retrieved from https://doi.org/10.1016/j.landurbplan.2018.01.005

Gulsrud, N. M., \& Ooi, C.-S. (2015). Manufacturing Green Consensus : Urban Greenspace Governance in Singapore Urban Forests, Trees, and Greenspace. Routledge, (October), 95110.

Haaland, C., \& van den Bosch, C. K. (2015). Challenges and strategies for urban green-space planning in cities undergoing densification: A review. Urban Forestry and Urban Greening, 14(4), 760-771. Retrieved from http://dx.doi.org/10.1016/j.ufug.2015.07.009

Henderson, J. C. (2013). Urban parks and green spaces in Singapore. Managing Leisure, 18(3), 213-225. https://doi.org/10.1080/13606719.2013.796181

IUCN Commission on Environmental Law. (2000). Landscape conservation law. Landscape Conservation Law: Present Trends and Perspectives in International and Comparative Law. IUCN, Gland, Switzerland and Cambridge, UK. 
Jansson, M., \& Lindgren, T. (2012). A review of the concept "management" in relation to urban landscapes and green spaces: Toward a holistic understanding. Urban Forestry and Urban Greening, 11(2), 139-145. https://doi.org/10.1016/j.ufug.2012.01.004

Jansson, M., Vogel, N., Fors, H., Randrup, T. B., Jansson, M., Vogel, N., ... Randrup, T. B. (2018). The governance of landscape management: new approaches to urban open space development urban open space development. Landscape Research, 00(00), 1-14. https://doi.org/10.1080/01426397.2018.1536199

Kalantari, F., Tahir, O. M., Joni, R. A., \& Fatemi, E. (2018). Opportunities and Challenges in Sustainability of Vertical Farming : A Review. Journal of Landscape Ecology, 11(1), 35-60. https://doi.org/10.1515/jlecol-2017-0016

KPKT. (2018). Senarai Dasar KPKT. Retrieved February 2, 2018, from http://www.kpkt.gov.my/index.php/pages/view/32

Kumar, R. (2014). Susttainable Urban Lanscape. Swedish University of Agricultural Sciences Faculty of Landscape Planning, Horticulture and Agricultural Sciences.

Londonassembly. (2018). Greener City Fund. Retrieved May 20, 2018, from https://www.london.gov.uk/what-we-do/environment/parks-green-spaces-and-biodiversity/ greener-city-fund

Mahayudin, M., Mohd Yunos, M. Y., Othuman Mydin, M. A., \& Tahir, M. O. (2015). Developing a Sustainable Campus Landscape Criteria : An Evaluation Universiti Pendidikan Sultan Idris as a Green Campus. Advances in Environmental Biology, 9(4), 201-205.

MAIL. (2016). Natural resources management national program. ministry of agriculture, irrigaiton and livestock.

Mann, C., Garcia-martin, M., Raymond, C. M., Shaw, B. J., \& Plieninger, T. (2018). Landscape and Urban Planning The potential for integrated landscape management to ful fi 1 Europe' s commitments to the Sustainable Development Goals. Landscape and Urban Planning, 177(April), 75-82. https://doi.org/10.1016/j.landurbplan.2018.04.017

McGarigal, K. (2014). what is landscape? Uinversity of Massachusetts Amherst. Retrieved July 15, 2014, from www.umass.edu/landeco/teaching/landscape_ecology/.../ chapter3_landscape.pdf

Mukherjee, M., \& Takara, K. (2018). Urban green space as a countermeasure to increasing urban risk and the UGS-3CC resilience framework. International Journal of Disaster Risk Reduction.

Nölting, B., \& Mann, C. (2018). Governance strategy for sustainable land management and water reuse : Challenges for transdisciplinary research. Sustainable Development., (January), 1-10. https://doi.org/10.1002/sd.1739

Nor Akmar, A. A. (2012). Green space use and management in Malaysia. Frederiksberg: Forest \& Landscape, University of Copenhagen.

Ojeda-Revah, L., Bojorquez, I., \& Osuna, J. C. (2017). How the legal framework for urban parks design affects user satisfaction in a Latin American city. Cities, 69(June), 12-19. Retrieved October 17, 2017, from http://dx.doi.org/10.1016/j.cities.2017.05.016

Pearson, L. J., \& Moon, K. (2014). Landscape and Urban Planning A novel method for assessing integration activities in landscape management. Landscape and Urban Planning, 130, 201-205. https://doi.org/10.1016/j.landurbplan.2014.06.008

Prakash, R., \& Tan, P. (2014). Landscape of Social Enterprises in Singapore Centre for Social Entrepreneurship \& Philanthropy (ACSEP). 
Darkhani F., Mohd Tahir O., Ibrahim R.: Sustainable Urban Landscape Management: An Insight into Urban Green Space Management Practices in Three Different Countries

Rakhshandehroo, M., Mohd Yusof, M. J., Tahir, O. M., \& Mohd Yunos, M. Y. (2015). the Social Benefits of Urban Open Green Spaces : a Literature Review. Management Research and Practice, 7 (4), 60.

Rakhshandehroo, M., Yusof, M. J. J. M., Arabi, R., \& Jahandarfard, R. (2016). Strategies To Improve Sustainability in Urban Landscape ,. Journal of Landscape Ecology, 9(3), 5-13.

Shaker, R. R. (2018). Examining sustainable landscape function across the Republic of Moldova. Habitat International, 72, 77-91. https://doi.org/10.1016/j.habitatint.2016.11.002

Shields, B. P., Moore, S. A., \& Eagles, P. F. J. (2016). PARKS. The International Journal of Protected Areas and Conservation,22.1, 101. Retrieved August 6, 2016, from https://www.iucn.org/sites/dev/files/parks_20.2_low_resolution_10.2305-iucn.ch_.2014.par ks-20-2.pdf

Solecka, I., Raszka, B., \& Krajewski, P. (2018). Land Use Policy Landscape analysis for sustainable land use policy : A case study in the municipality of Popielów, Poland. Land Use Policy, 75, 116-126. Retrieved November 30, 2018, from https://doi.org/10.1016/ j.landusepol.2018.01.021

Space, C. A. B. E. (2006). Paying for parks. eight models for funding urban green spaces. Retrieved from www.cabe.org.uk

Stauffacher, M., \& Krütli, P. (2016). Sustainable Landscape Development. In Sustainability Science (pp. 207-217). Springer, Dordrecht. https://doi.org/https://doi.org/10.1007/ 978-94-017-7242-6_17

Strien, M. J. van, Slager, C. T. J., Vries, B. de, \& Gret-Regamey, A. (2016). An improved neutral landscape model for recreating real landscapes and generating landscape series for spatial ecological simulations. Ecology and Evolution, 6(11). https://doi.org/ 10.1002/ece3.2145

Tahir, O. M., \& Roe, M. H. (2006). Sustainable urban landscapes: making the case for the development of an improved management system. Intl J. on Sustainable Tropical Design Research \& Practices, 1 (1), 17-23.

Tan, P. Y., Wang, J., \& Sia, A. (2013). Perspectives on five decades of the urban greening of Singapore. Cities, 32, 24-32. https://doi.org/10.1016/j.cities.2013.02.001

TKPK. (2018). Profil. Retrieved August 25, 2018, from http://www.kpkt.gov.my/ index.php/pages/view/312?mid

Uyl, R. M. Den, \& Driessen, P. P. J. (2015). Evaluating governance for sustainable development e Insights from experiences in the Dutch fen landscape. Journal of Environmental Management, 163, 186-203. https://doi.org/10.1016/j.jenvman.2015.08.022

Wilson, O., \& Hughes, O. (2011). Urban green space policy and discourse in England under new labour from 1997 to 2010. Planning Practice \& Research, 26 (2), 207-228. https://doi.org/10.1080/02697459.2011.560462

Yoong, H. Q., Lim, K. Y., Lee, L. K., Zakaria, N. A., \& Foo, K. Y. (2017). Sustainable urban green space management practice. Symposium on Innovation and Creativity (IMIT-SIC), 2, $1-4$. 